UDC 622.276.6

Review / Обзор

(c) PNRPU / ПНИПУ, 2020

\title{
Estimating the Potential of Unmanned Aerial Vehicle Use in the Oil and Gas Industry
}

\section{Anastasia D. Anikaeva, Dmitry A. Martyushev}

Perm National Research Polytechnic University (29 Komsomolskiy av., Perm, 614990, Russian Federation)

\section{Оценка потенциала применения беспилотных летательных аппаратов в нефтегазовой отрасли}

\section{А.Д. Аникаева, Д.А. Мартюшев}

Пермский национальный исследовательский политехнический университет (Россия, 614990, г. Пермь, Комсомольский пр., 29)

\section{Received / Получена: 20.03.2020. Accepted/ Принята: 25.08.2020. Published / Опубликована: 26.10.2020}

Keywords:

airborne photographic survey, unmanned aerial vehicle, unmanned system, images, orthophotoplan, altitude map, topographic model, manned aerial photography, oil and gas industry, software products, topographic plan, monitoring of facilities, oil spills, pipelines, illegal activity.
Ключевые слова: аэрофотосъемка, беспилотный летательный аппарат, беспилотный комплекс, снимки, ортофотоплан, карта высот, модель местности, пилотируемая аэрофотосъемка, нефтегазовая отрасль, программные продукты, топографический план, мониторинг объектов, разливы нефти, трубопроводы, незаконная деятельность.
The relevance of the study is explained by the need to use unmanned aerial vehicles (UAV) to serve engineering and geodetic tasks in the oil and gas industry. Airborne photographic survey using unmanned aerial vehicles is currently an advanced technology in the area of geodesy and it replaces such methods as tacheometry, satellite-based positioning in RTK modes, manned aerial photography, and aiborne laser scanning (ALS). The potential for using UAVs in the oil and gas industry today is truly enormous. Numerous safety and reliability problems, which traditionally have been cost consuming for oil and gas companies, can be effectively addressed using UAVs. The study included processing of data obtained from the unmanned complex in three modern software packages (Agisoft Photoscan Professional, v 1.2.5.2594 (Russia), ERDAS IMAGINE, v 2015 (USA) and Pix4Dmapper Pro (Switzerland)) of various automation degrees; assessment of accuracy in ArcMap software by superimposing a topographic plan on an orthomosaic with a scale of 1 : 500 on the territory under consideration; calculation of economic and labor costs. As part of the study, it was proved that the use of UAVs was possible not only for the geodetic work, but also for solving other equally important tasks of the oil and gas industry, which leads to a decrease in economic and environmental risks, automation of processes related to monitoring of oil facilities, prevention of illegal attempts of pipeline tie-ins, oil spills. In addition, based on the obtained orthophotomaps, the economic, accuracy and labor-time feasibility of using unmanned systems were confirmed. It has been established that the use of unmanned aerial vehicles in various fields of oil and gas activities for solving engineering and geodetic problems is an integral part of any company engaged in the production and transportation of hydrocarbons.

Актуальность работы обусловлена необходимостью использования беспилотных летательных аппаратов (БПлА) для решения инженерно-геодезических задач в нефтегазовой промышленности. Аэрофотосъемка беспилотными летательными аппаратами в настоящее время является передовой технологией в области геодезии, вытесняя такие методы, как тахеометрия, спутниковое позиционирование в режимах RTK, пилотируемая аэрофотосъемка, воздушное лазерное сканирование (ВЛС). Потенциал использования БПЛА в нефтегазовой отрасли на сегодняшний момент поистине огромен. Многие вопросы безопасности и надежности, на которые компании нефтегазовой отрасли традиционно тратят существенные средства, могут эффективно решаться с использованием БПЛА. Осуществлены: обработка данных, полученных с беспилотного комплекса в трех современных программных продуктах (Agisoft Photoscan Professional, v 1.2.5.2594 (Россия), ERDAS IMAGINE, v 2015 (США) и Pix4Dmapper Pro (Швейцария)) различной степени автоматизации; оценка точности в ПО ArcМар посредством наложения топографического плана на ортофотоплан масштабного ряда 1:500 на рассматриваемую территорию; подсчет экономических и трудовременных затрат. В рамках выполнения исследования доказано, что использование БПЛА возможно не только для геодезических работ, но также и для решения других, не менее важных задач нефтегазовой отрасли, что приводит к снижению экономических и экологических рисков, автоматизации процессов, связанных с мониторингом нефтеобъектов, предотвращению попыток незаконных врезок в трубопровод, разливов нефти. Также на основании полученных ортофотопланов подтверждена экономическая, точностная и трудовременная целесообразность использования беспилотных комплексов. Установлено, что применение беспилотных летательных аппаратов в различных сферах нефтегазовой деятельности для решения инженерно-геодезических задач является неотъемлемой частью любой компании, занимающейся добычей и транспортировкой углеводородов.

Anastasia D. Anikaeva - PhD Student at the Department of Mine Surveying, Geodesy and Geoinformation Systems (tel.: +007342 219 8088 , e-mail: anast.anickaeva@yandex.ru).

Dmitry A. Martyushev (Author ID in Scopus: 56308102400) - PhD in Engineering, Associate Professor at the Department of Oil and Gas Technologies (tel.: + 0073422198250 , e-mail: martyushevd@inbox.ru). The contact person for correspondence.

Аникаева Анастасия Дмитриевна - аспирант кафедры «Маркшейдерское дело, геодезия и геоинформационные системы» (тел.: +007 3422198088 , e-mail: anast.anickaeva@yandex.ru).

Мартюшев Дмитрий Александрович - кандидат технических наук, доцент кафедры «Нефтегазовые технологии» (тел.: +007 342 219 8250 , e-mail: martyushevd@inbox.ru). Контактное лицо для переписки. 


\section{Introduction}

Airborne photographic surveying with the use of unmanned aerial vehicles (UAV) is currently an advanced technology in the field of geodesy; and it replaces such methods as tacheometry, satellitebased positioning in RTK modes, manned aerial photography, and airborne laser scanning (ALS). This is due to the lack of their competitiveness in terms of the following two basic criteria, i.e. cost and time required to complete works [1-7].

Today, the potential of UAV use in the oil and gas industry is really immense. Many safety and reliability problems, which traditionally have been cost consuming for oil and gas companies, can be effectively addressed using UAVs. It should be noted that the value of the unmanned aerial systems includes innovative software designated for recognition and processing of data obtained from UAV [8-14].

The use of new advanced solutions based on the unmanned technologies provides significant advantages to oil and gas companies, for instance, in engineering and geodetic fields, beginning with the monitoring of linear facilities (oil pipelines, water pipelines, gas pipelines, and power transmission lines) up to preparations of surveying plans [15-27].

UAV system makes it possible to get real-time high quality aerial photographs, videos, etc. A wide range of UAV functions allows surveying in visible and infrared ranges, shooting with a multispectral camera, thus, enhance functionality in conditions of a limited visibility. High battery performances in combination with long distance video transmissions make it possible to perform work by covering vast areas [28-32].

At the moment, in the territory of Perm Krai, the use of UAV is developing, while preferences are still given to conventional methods (tacheometry to prepare surveying plans and human resource involvement to monitor linear facilities). To illustrate a wide range of unmanned aerial vehicle functions, which can be used in the territory of Perm Krai, and to specify new applications, we used SenseFlyeBee aerial vehicle at one of the facilities belonging to an oil and gas company (the area of the territory of interest is 13.6 hectares). Images obtained from the UAV were processed, results of processing by different advanced software products were compared, and the economic effect of UAV use was demonstrated, as compared to the conventional geodetic methods, which are currently in use. Fig. 1 shows the UAV flight route at the oil and gas site of interest.

\section{Orthophotoplan Preparation}

As a result of SenseFlyeBee flights, 49 images in .jpg format were obtained. The images were processed by three software products, which are considered to be the best in their field: Agisoft Photoscan Professional, v 1.2.5.2594 (Russia), ERDASIMAGINE, v 2015 (USA) and Pix4DmapperPro (Switzerland). Fig. 2 demonstrates altitude mapping, an intermediate stage of the data processing.

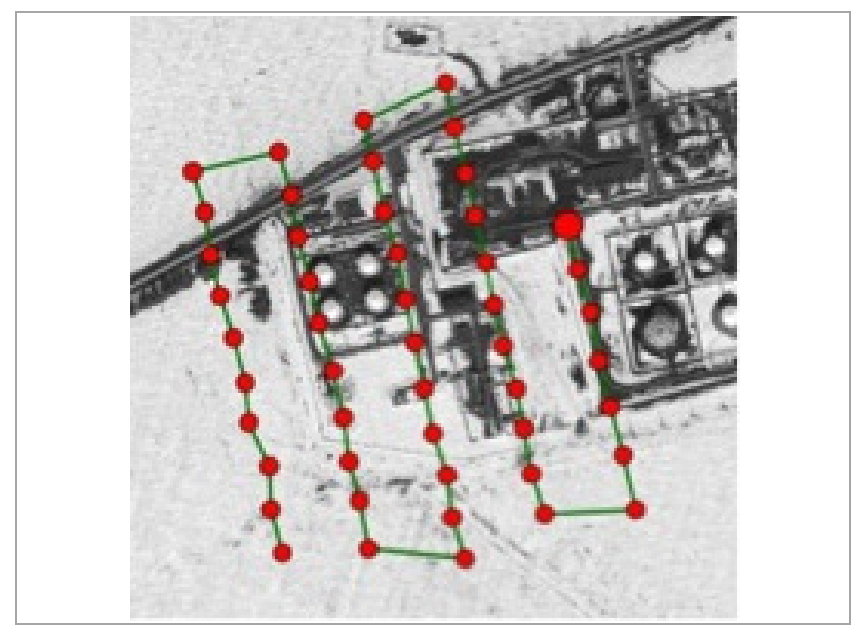

Fig.1. The rout plan of SenseFlyeBee unmanned aerial vehicle flight above the facility of interest

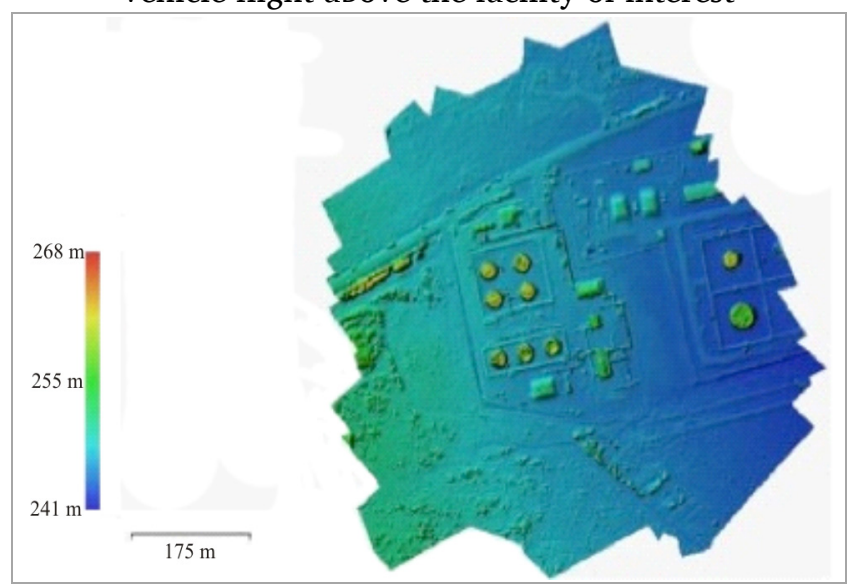

Fig.2. The altitude map of the facility of interest built in Agisoft Photoscan Professional, v 1.2.5.2594 


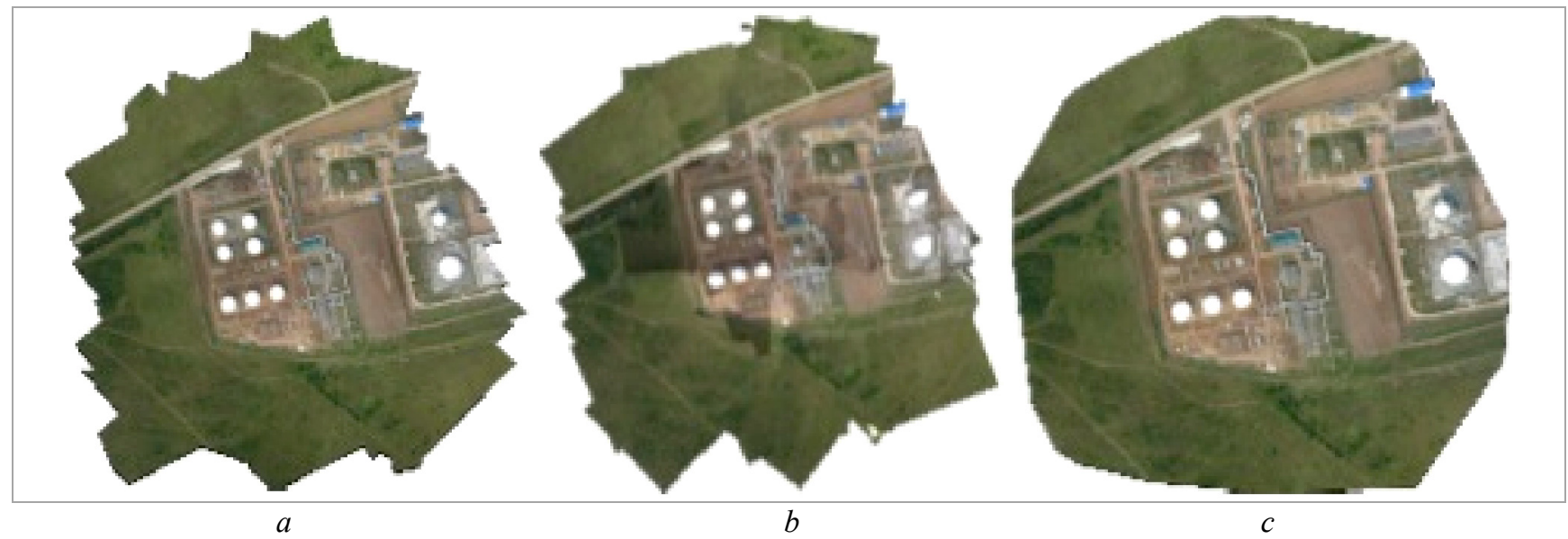

Fig.3. View of a ready orthophotoplan obtained in the following software products: a) Agisoft Photoscan Professional, v 1.2.5.2594; b) ERDASIMAGINE, v 2015; c) Pix4DmapperPro

Table 1

Fig. 3 shows the final results of the data processing by the UAV in view of orthophotoplans. In the oil and gas industry, orthophotoplans allow presenting a situation on the ground surface providing as much details as possible; therefore, the quality of orthophotoplans is to be of a high level (empty zones and stitching lines shall not be seen).

Based on the analysis results, we can conclude that the orthophotoplan produced by ERDASIMAGINE (Fig. 3, b) cannot be further used in the research, as it contains a lot of blind zones, facilities are much distorted, and image stitching lines are clearly seen. In addition, it should be noted that the preparation of orthophotoplans in this software product is a rather time consuming, as it is mainly based on seaming space images and aerial photographs (obtained from the manned aerial vehicles) where tilt angles are small or close to zero. In the example given, UAV images obtained at angles significantly different from zero need to be processed.

\section{The Assessment of the Accuracy of Prepared Orthophotoplans}

In order to assess the accuracy of prepared orthophotoplans, and, therefore, find the most efficient software, a geodetic assessment of accuracy was performed with the use of ArcMap, v 10.5.
Facility location error limit

\begin{tabular}{ll}
\hline \multicolumn{1}{c}{ Facility } & $\begin{array}{c}\text { At a scale of a map } \\
\text { or a plan, mm }\end{array}$ \\
\hline $\begin{array}{l}\text { Geodetic network control stations, } \\
\text { landmarks }\end{array}$ & 0.2 \\
\hline Clearly outlined facilities & 0.5 \\
$\begin{array}{l}\text { Unclearly outlined facilities and facilities } \\
\text { in mountain areas, high mountain areas, } \\
\text { and desert regions }\end{array}$ & 0.75 \\
\hline
\end{tabular}

In accordance with LUKOIL's industry standard STO 1.8.-2008 Digital topographic maps and plans: requirements concerning the content, structure, presentation format, and update rules in LUKOIL JSC and LUKOIL group companies, the requirements concerning positioning accuracy that specify error limits, as compared to actual values, for the location of facilities on digital topographic maps and plans are given in Table 1 [33-38].

Based on Table 1, error limits for clearly outlined locations of objects are $0.5 \mathrm{~mm}$ at a scale of a map or a plan. For a scale of 1:500, with regard to such error limits, the error limit in a plain view is going to be $0.25 \mathrm{~m}$, and a vertical view error limit is going to be $0.16 \mathrm{~m}(1 / 3$ of vertical interval) [39-42].

The surveying plans were prepared in ArcMap, v 10.5, software product by overlaying a topographic plan on an orthophotoplan with regard to all requirements at a scale of $1: 500$ (Fig. 4) [43-45]. 
On completion of accuracy assessment and based on the obtained results, we can conclude that the most accurate software for the processing of data obtained from UAV is Pix4Dmapper Pro.This is due to the fact that at a scale of 1:500, its error in plain view was $3 \mathrm{~cm}$, and vertical view error was $9 \mathrm{~cm}$. The assessment of the software accuracy, price, and cost effectiveness is given in Table 2.

Expenses associated with the preparation of an orthophotoplan of the facility of interest with the use of UAV are times less vs. those needed for conventional shooting. In case of conventional orthophotoplan building method, the approximate cost of one hectare of a densely built-over territory will vary in the range of $75,000-100,000$ rubles; whereas, the use UAV falls in the range of 10,000-13,000 rubles. Hence, the cost of imaging of the territory with the use of UAV and further seaming of the orthophotoplan amounted to $130,479.09$ rubles.

In addition to geodetic activities, UAV can be used in dealing with other equally important tasks in the oil and gas industry, for instance, monitoring of cluster sites and construction of liner facilities (oil and gas pipelines), as well as in solving environmental problems arising during operations of wells and pipelines. Normally, in the real-time mode UAVs allow receiving good quality images that enable detecting oil spills and illegal activities.

\section{Geodetic Monitoring of the Earthwork at Cluster Sites and Monitoring the Construction of Linear Facilities}

The construction and development of sites at oil production facilities include certain work associated with preparing a particular territory for a further installation of process equipment, production and amenity rooms, groups of wells (clusters), etc. The entire area of a cluster foundation shall be subjected to banking around the perimeter. Such measures are important as they provide conditions necessary for environmentally safe operations of oil fields.

Data obtained from UAV makes it possible to quickly build a model of a well cluster territory, calculate volumes, and save money. An example of a cluster site monitoring with the use of UAV is shown in Fig. 5.

Today, the construction monitoring of linear facilities in the oil and gas industry with the use of UAV is a mandatory step for any company in

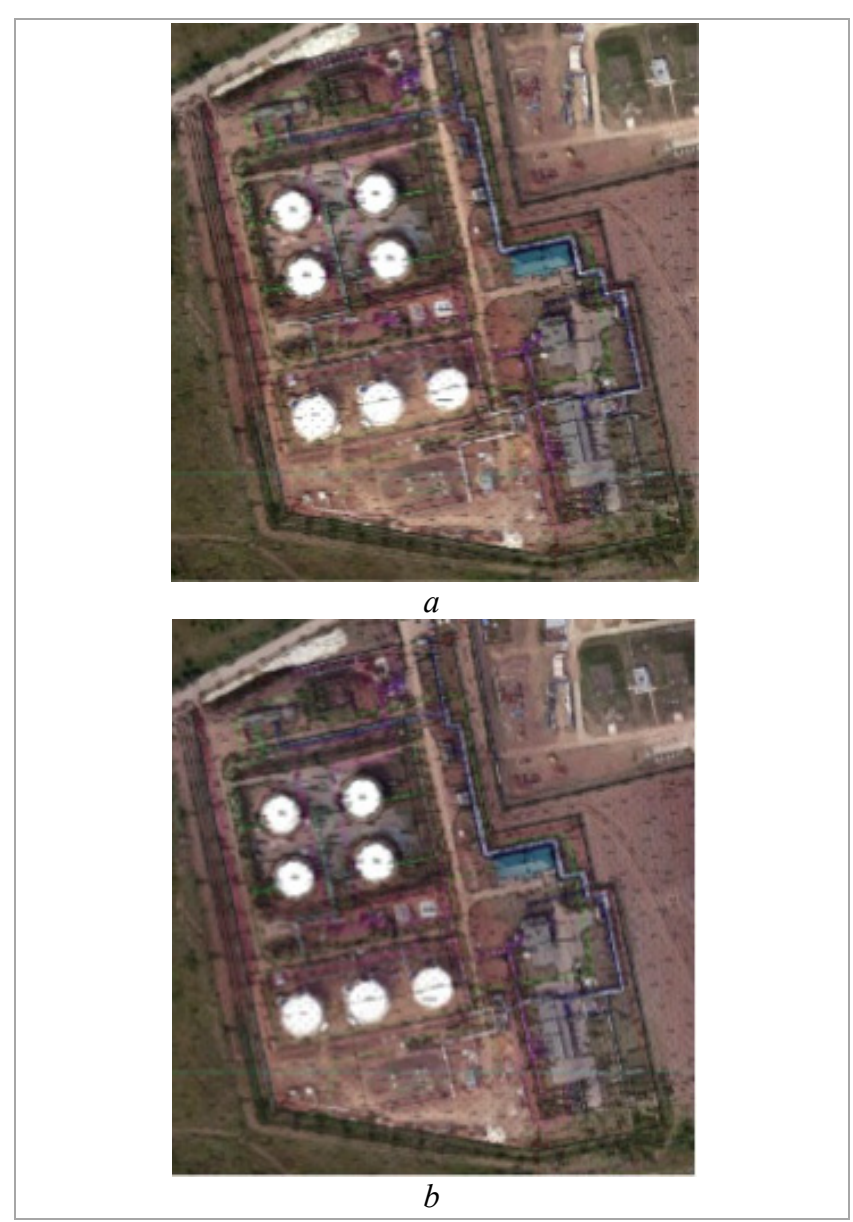

Fig. 4. Surveying plan obtained in the following software products: a) Pix4DmapperPro; b) Agisoft Photoscan Professional

Table 2

Comparative analysis of software products

\begin{tabular}{|c|c|c|}
\hline Parameter & $\begin{array}{l}\text { Pix4Dmapper Pro } \\
\text { (Switzerland) }\end{array}$ & $\begin{array}{c}\text { Agisoft Photoscan } \\
\text { Professional, } \\
\text { v 1.2.5.2594 } \\
\text { (Russia) }\end{array}$ \\
\hline Software price, rubles & 495,900 & 199,500 \\
\hline Automation degree & Fully automated & Semi-automated \\
\hline $\begin{array}{l}\text { Time required to process } \\
49 \text { images, } h\end{array}$ & 3 & 6 \\
\hline $\begin{array}{l}\text { Number of people needed } \\
\text { for processing }\end{array}$ & One & One \\
\hline $\begin{array}{l}\text { Accuracy assessment } \\
\text { (plain view/vertical } \\
\text { view), m/m }\end{array}$ & $0.03 / 0.09$ & $0.05 / 0.10$ \\
\hline
\end{tabular}


need to minimize risks, reduce costs, and enhance efficiency. Efficient maintenance operations of linear facilities require constant monitorings and services; however, it is not so easy to provide that. Fig. 6 shows a part of an oil pipeline where the difference between the design and actual position is clearly seen.

As a rule, UAV makes it possible to obtain good quality images in real-time modes to detect oil spills and illegal activities. Fig. 7 shows the results of processing the data obtained from UAV, which can be used to estimate the amount of the spilled oil and assess economic and environmental expenditures.

Therefore, the use of UAV is to enhance the quality and safety of operations, help to examine those elements of the process equipment components which are either hazardous, or inaccessible for personnel, unless the production process is stopped (for instance, flare systems), enable the prevention of illegal tapping attempts, save money, and mitigate environmental risks.

\section{Conclusion}

So, it has been found that the use of the unmanned aerial vehicles in different areas of the oil and gas industry to solve engineering and geodetic problems represents an integral part of activities of any company operating in the field of hydrocarbon production and transportation.

Advanced technologies based on the use of UAV mitigate economic risks by 5-10 times, automate processes associated with the monitoring of oil facilities, and enable the prevention of oil spills and attempts of illegal tapping.

Based on the orthophotoplans prepared in the following three software products: Agisoft Photoscan Professional, $\mathrm{v}$ 1.2.5.2594 (Russia), ERDASIMAGINE, v 2015 (USA), and Pix4DmapperPro (Switzerland), the costeffectiveness of using the unmanned systems was proved.

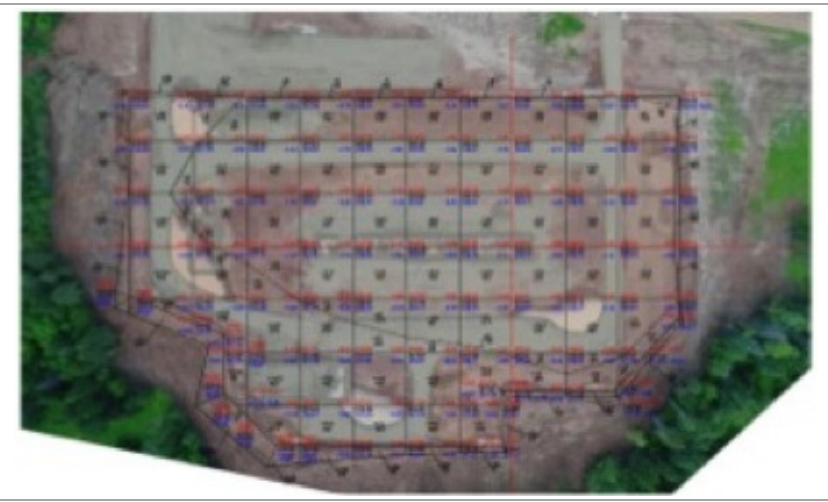

Fig. 5. Monitoring the earthwork at a cluster site

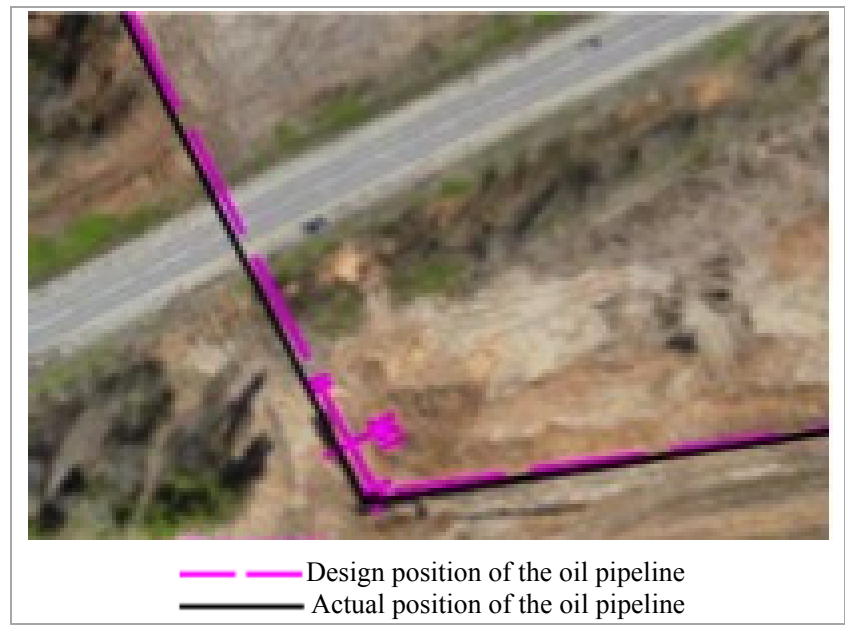

Fig. 6. Difference between the design and actual position of the oil pipeline
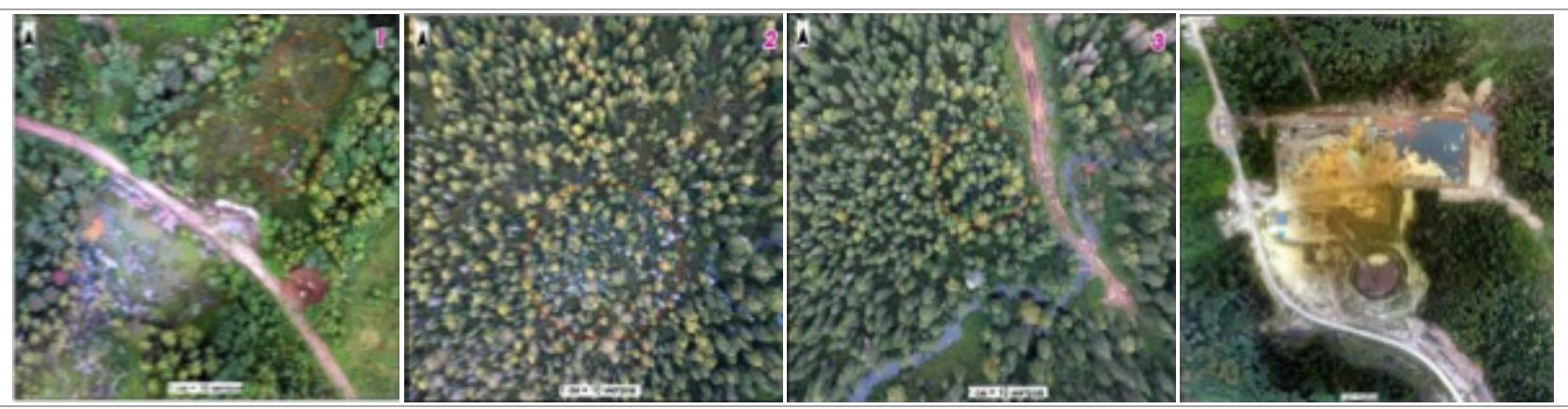

Fig. 7. An example of processing UAV data on an oil spill 


\section{References}

1. Dubbini M., Curzio L.I., Campedelli A. Digital elevation models from unmanned aerial vehicle surveys for archaeological interpretation of terrain anomalies: case study of the Roman castrum of Burnum (Croatia). Journal of Archaeological Science: Reports, 2016, vol. 8, pp. 121-134. DOI: $10.1016 / \mathrm{j}$.jasrep.2016.05.054

2. Lucieer Arko, Turner Darren, King Diana H., Robinson Sharon A. Using an Unmanned Aerial Vehicle (UAV) to capture micro-topography of Antarctic moss beds. International Journal of Applied Earth Observation and Geoinformation, 2014, vol. 27, pp. 53-62. DOI: 10.1016/j.jag.2013.05.011

3. Taimanova G.K., Pak R.E. Bespilotnye letatel'nye apparaty dlia monitoringa nefteprovodov [Unmanned aerial vehicles for monitoring oil pipelines]. International Scientific and Practical Conference World science, 2018, vol. 1, no. 1 (29), pp. $42-43$.

4. Chuenkova A.A., Logacheva A.V. Bespilotnye letatel'nye apparaty V geoinformatsionnoi sfere [Unmanned aerial vehicles in the field of geoinformation]. Konstruktorskoe biuro, 2018, no. 3, pp. 34-42.

5. Iamshchikov V.A. Bespilotnye letatel'nye apparaty [Unmanned aerial vehicles]. Internauka, 2019, no. 45-1 (127). pp. 75-77.

6. Smirnova M.S. Osobennosti razrabotki i obespecheniia kachestva programmnykh kompleksov upravleniia gruppirovkami bespilotnykh letatel'nykh apparatov [Features of development and quality assurance of software systems for managing unmanned aerial vehicle groupings]. Nauka $i$ biznes: puti razvitiia, 2019, no. 7 (97), pp. 119-123.

7. Podshivalova K.S., Podshivalov S.F., Komolova N.V., Pavlova Iu.A., Dunaev S.V. Raschet marshrutov dlia gruppy bespilotnykh apparatov [Calculation of routes for the group of unmanned vehicles].
Dnevnik nauki, 2019, no. 10

(34), pp. 13-15.

8. Gabrlik P. The Use of Direct Georeferencing in Aerial Photogrammetry with Micro UAV. IFAC-PapersOnLine, 2015, vol. 48, iss. 4, pp. 380-385. DOI: $10.1016 /$ j.ifacol.2015.07.064

9. Satoshi Ishiguro, Hiroya Yamano, Hiroyuki Oguma Evaluation of DSMs generated from multi-temporal aerial photographs using emerging structure from motion-multi-view stereo technology. Geomorphology, 2016, vol. 268, pp. 64-71. DOI: 10.1016/j.geomorph.2016.05.029

10. Aber J.S., Marzolff I., Ries J.B. Chapter 1: Introduction to Small-Format Aerial Photography. Small-Format Aerial Photography, 2010, pp. 1-13. DOI: 10.1016/B978-0-12-812942-5.00001-X

11. Stefano G. Di, Romeo G., Mazzini A., Iarocci A., Pelphrey S. The Lusi drone: A multidisciplinary tool to access extreme environments. Marine and Petroleum Geology, 2018, vol. 90, pp. 26-37. DOI: 10.1016/j.marpetgeo.2017.07.006

12. Colomina I., Molina P. Unmanned aerial systems for photogrammetry and remote sensing: A review. ISPRS Journal of Photogrammetry and Remote Sensing, 2014, vol. 92, pp. 79-97. DOI: 10.1016/j.isprsjprs.2014.02.013

13. Siebert S., Teizer J. Mobile 3D mapping for surveying earthwork projects using an Unmanned Aerial Vehicle (UAV) system. Automation in Construction, 2014, vol. 41, pp. 1-14. DOI: 10.1016/j.autcon.2014.01.004

14. Margaret Arblaster 11: New entrants into airspace - unmanned aircraft (drones) and increased space transportation. Air traffic management, 2018, pp. 235-255. DOI: 10.1016/B978-0-12-811118-5.00011-4

15. STO "LUKOI" 1.8.-2008. Karty i plany tsifrovye topograficheskie, Trebovaniia $\mathrm{k}$ sostavu, strukture, soderzhaniiu, formatam predstavleniia, pravilam obnovleniia $\mathrm{v}$ OAO "Lukoil" i organizatsiiakh gruppy "Lukoil" [STO "LUKOY" 1.8.-2008. Digital topographic maps and plans, Requirements for composition, structure, content, presentation formats, 
updating rules in OJSC Lukoil and organizations of the Lukoil group]. Perm, 2008, 45 p.

16. Rukovodstvo pol'zovatelia Agisoft PhotoScan Professional Edition, versiia 1.2. 2004 [Agisoft PhotoScan Professional Edition User Manual, version 1.2. 2004]. Moscow, 2004, $90 \mathrm{p}$.

17. Krasnopevtsev B.V. Fotogrammetriia [Photogrammetry]. Moscow: UPP "Reprografiia" MIIGAiK, 2008, 160 p.

18. Toktoshov G.Y. O sozdanii geoinformatsionnykh sistema na osnove gipersetei dlia organizatsii inzhenernoi infrastruktury sovremennykh gorodov [On creation of geographic information systems based on hypernetworks for the organization of the engineering infrastructure of modern cities]. Izvestiia Tomskogo politekhnicheskogo universiteta. Inzhiniring georesursov, 2016, vol. 327, no. 1, pp. 48-55.

19. Koviazin V.F., Romanchikov A.Iu. Metod kadastrovoi otsenki lesnykh zemel' $\mathrm{s}$ predstavleniem rezul'tatov $\mathrm{v}$ vide geoinformatsii [Method of forestland cadastral evaluation with results presentation as geologic informational]. Izvestiia Tomskogo politekhnicheskogo universiteta. Inzhiniring georesursov, 2017, vol. 328, no. 2, pp. 104-112.

20. Dadashov I.F., Loboichenko V.M., Strelets V.M., Gurbanova M.A., Gadzhizade F.M., Morozov A.I. Ob ekologicheskikh kharakteristikakh ognetushashchikh veshchestv, ispol'zuemykh pri tushenii nefti i nefteproduktov [About the Environmental Characteristics of Fire Extinguishing Substances Used in Extinguishing Oil and Petroleum Products]. SOCAR Proceedings, 2020, no. 2, pp. 79-84. DOI: 10.5510/OGP20200100425

21. Aliguliev R.M., Fataliev T.Kh., Mekhtiev Sh.A. Promyshlennyi internet veshchei: evoliutsiia avtomatizatsii $\mathrm{v}$ neftegazovom komplekse [The industrial internet of things: the evolution of automation in the oil and gas]. SOCAR Proceedings, 2019, no. 2, pp. 66-71. DOI: 10.5510/OGP20190200391
22. Shammazov A.M., Shammazov I.A., Smorodova O.V., Kitaev S.V., Baikov I.R. Optimizatsiia energeticheskoi strategii neftegazovogo predpriiatiia [Optimization of the oil and gas companies energy strategy]. SOCAR Proceedings, 2018, no. 4, pp. 65-69. DOI: $10.5510 / O G P 20180400373$

23. Kremcheev E.A., Danilov A.S., Smirnov Iu.D. Sostoianie metrologicheskogo obespecheniia sistem monitoringa na baze bespilotnykh vozdushnykh sudov [Metrological support of monitoring systems based on unmanned aerial vehicles]. Zapiski gornogo instituta, 2019, vol. 235, pp. 96-105. DOI: 10.31897/PMI.2019.1.96

24. Catur Aries Rokhmana The Potential of UAV-based Remote Sensing for Supporting Precision Agriculture in Indonesia. Procedia Environmental Sciences, 2015, vol. 24, pp. 245-253. DOI: 10.1016/j.proenv.2015.03.032

25. Xiu quan Li, Zhu and Chen, Li ting Zhang, Dan Jia. Construction and Accuracy Test of 3D Model of Non-Metric Camera Images Using Agisoft PhotoScan. Procedia Environmental Sciences, 2016, vol. 36, pp. 184-190. DOI: $10.1016 /$ j.proenv.2016.09.031

26. Pajares G., Overview and Current Status of Remote Sensing Applications Based on Unmanned Aerial Vehicles (UAVs). Photogrammetric Engineering \& Remote Sensing, 2015, vol. 81, iss. 4. pp. 281-329. DOI: $10.14358 /$ PERS.81.4.281

27. Bhardwaj Anshuman, Sam Lydia, Akanksha F., Martín-Torres Javier, Kumar Rajesh. UAVs as remote sensing platform in glaciology: Present applications and prospects. Remote Sensing of Environment, 2016, vol. 175, pp. 196-204. DOI: $10.1016 /$ j.rse.2015.12.029

28. Men'shikov S.N., Dzhaliabov A.A., Vasil'ev G.G., Leonovich I.A., Ermilov O.M. Prostranstvennye modeli, razrabatyvaemye $\mathrm{s}$ primeneniem lazernogo skanirovaniia na gazokondensatnykh mestorozhdeniiakh Severnoi stroitel'no-klimaticheskoi zony [Spatial Models Developed Using Laser Scanning at Gas Condensate Fields in the Northern Construction-Climatic Zone]. Zapiski gornogo 
instituta, 2019, vol. 238, pp. 430-437. DOI: $10.31897 /$ pmi.2019.4.430

29. Averbukh V.L., Averbukh N.V., Vasev P.A., Gvozdarev I.L., Levchuk G.I., Melkozerov L.O. Vizualizatsiia programmnogo obespecheniia na baze sredstv virtual'noi real'nosti geoprostrastvennykh dannykh. Obzor i perspektivy razrabotki [Software visualization of geospatial data based on virtual reality systems. Survey and future developments]. Izvestiia Tomskogo politekhnicheskogo universiteta. Inzhiniring georesursov, 2020, vol. 331, no. 1, pp. 195-210. DOI: $10.18799 / 24131830 / 2020 / 1 / 2461$

30. Zoev I.V., Markov N.G., Ryzhova S.E. Intellektual'naia sistema komp'iuternogo zreniia bespilotnykh letatel'nykh apparatov dlia monitoringa tekhnologicheskikh ob"ektov predpriiatii neftegazovoi otrasli [Intelligent computer vision system for unmanned aerial vehicles for monitoring technological objects of oil and gas industry]. Izvestiia Tomskogo politekhnicheskogo universiteta. Inzhiniring georesursov, 2019, vol. 330 , no. 11 , pp. 34-49. DOI: $10.18799 / 24131830 / 2019 / 11 / 2346$

31. Latypov A.I., Iabbarova E.N. Ob interpretatsii dannykh staticheskogo zondirovaniia gruntov [On interpretation of the data of soil cone penetration tests]. Izvestiia Tomskogo politekhnicheskogo universiteta. Inzhiniring georesursov, 2019, vol. 330, no. 10, pp. 82-90. DOI: $10.18799 / 24131830 / 2019 / 10 / 2300$

32. Karpik A.P., Avrunev E.I., Dobrotvorskaia N.I., Dubrovskii A.V., Malygina O.I., Popov V.K. Organizatsiia sistemy geoinformatsionnogo monitoringa sostoianiia zemel'nykh resursov pribrezhnoi zony Novosibirskogo vodokhranilishcha [Organization of the system of geoinformation monitoring the land resources in Novosibirsk basin shore zone]. Izvestiia Tomskogo politekhnicheskogo universiteta. Inzhiniring georesursov, 2019, vol. 330 , no. 8 , pp. 133-145. DOI: $10.18799 / 24131830 / 2019 / 8 / 2219$

33. Epifanova E.A., Strokova L.A. Analiz deformatsii prozhektornoi machty pri pomoshchi nazemnogo lazernogo skanirovaniia i metoda konechnykh elementov [Numerical analysis of deformations of the lighting mast by ground laser scanning and finite elements method]. Izvestiia Tomskogo politekhnicheskogo universiteta. Inzhiniring georesursov, 2019, vol. 330, no. 5, pp. 7-17. DOI: $10.18799 / 24131830 / 2019 / 5 / 267$

34. Bharat Rao, Ashwin Goutham Gopi, Romana Maione The societal impact of commercial drones. Technology in society, 2016, vol. 45, pp. 83-90. DOI: 10.1016/j.techsoc.2016.02.009

35. Martin Cecilia, Parkes Stephen, Zhang Qiannan, Zhang Xiangliang, Carlos M. Duarte Use of unmanned aerial vehicles for efficient beach litter monitoring. Marine pollution bulletin, 2018, vol. 131, pp. 662-673. DOI: 10.1016/j.marpolbul.2018.04.045

36. Konar B., Iken K. The use of unmanned aerial vehicle imagery in intertidal monitoring. Deep-sea research part II: topical studies in oceanography, 2018, vol. 147, pp. 79-86. DOI: $10.1016 /$ j.dsr2.2017.04.010

37. Cho Jaeyoung, Lim Gino, Biobaku Taofeek, Kim Seonjin, Parsaei Hamid. Safety and security management with unmanned aerial vehicle (UAV) in oil and gas industry. Procedia manufacturing, 2015, vol. 3, pp. 1342-1349. DOI: $10.1016 /$ j.promfg.2015.07.290

38. Volkova I.I., Belov N.S., Shaplygina T.V. Geoprostranstvennyi analiz prirodnoantropogennoi transformatsii eolovykh pribrezhnomorskikh prirodnykh kompleksov s ispol'zovaniem nazemnogo lazernogo skanirovaniia [Geospatial analysis of natural-anthropogenic transformation of aeolian coastal-marine natural complexes using terrestrial laser scanning ]. Marksheiderskii vestnik, 2020, no. 1 (134), pp. 41-45.

39. Prokop A.D. Obosnovanie tochnosti opredeliaemykh velichin pri proizvodstve marksheiderskikh s"emok $s$ primeneniem programmno-apparatnykh kompleksov [Justification of the accuracy of the determined values in the production of surveying surveys using software and hardware systems]. Marksheiderskii vestnik, 2020, no. 1 (134), pp. 46-49. 
40. Pavlov V.I. Aerofotos"emka vodnogo prostranstva [Aerial photography of the water area]. Marksheiderskii vestnik, 2019, no. 6 (133), pp. 40-44.

41. Volkov V.I., Volkov N.V., Volkov O.V. Novyi podkhod $\mathrm{k}$ primeneniiu marksheiderskogeodezicheskikh nabliudenii dlia kontrolia tekhnogennykh posledstvii razrabotki neftegazovykh mestorozhdenii [New concept of usage of mine surveying and geodetic observations for monitoring the technogenic consequences of the development of oil and gas fields]. Marksheiderskii vestnik, 2018, no. 3 (124), pp. 45-50.

42. Chan T.Sh., Kuzin A.A. Analiz vliianiia krivizny Zemli na rezul'taty sputnikovykh i traditsionnykh izmerenii $\mathrm{v}$ topotsentricheskoi sisteme koordinat [Analysis of the influence of the Earth's curvature on the results of satellite and traditional measurements in a topocentric coordinate system]. Marksheiderskii vestnik, 2018, no. 6 (127), pp. 38-43.

43. Verdiev S.B. Analiz pogreshnosti geodezicheskikh sredstv izmereniia distantsii, vyzvannykh atmosfernymi osadkami [Analysis of error of geodetic instruments for measuring of distances caused by atmospheric factors]. Marksheiderskii vestnik, 2018, no. 6 (127), pp. 44-48.

44. Klochkov V.V., Nikitova A.K. Metody prognozirovaniia sprosa na bespilotnye letatel'nye apparaty i raboty po vozdushnomu patrulirovaniiu [Methods for predicting demand for unmanned aerial vehicles and aerial patrol operations]. Problemy prognozirovaniia, 2007, no. 6 (105), pp. 144-152.

45. Nikishev V.K., Sergeev E.S. Bespilotnye letatel'nye apparaty - modelirovanie dinamiki i perspektivy razvitiia [Unmanned aerial vehicles - dynamics modeling and development prospects]. Teoreticheskie $i$ prikladnye aspekty sovremennoi nauki, 2014, no. 6-3, pp. 85-87.

\section{Библиографический список}

1. Dubbini M., Curzio L.I., Campedelli A. Digital elevation models from unmanned aerial vehicle surveys for archaeological interpretation of terrain anomalies: case study of the Roman castrum of Burnum (Croatia) // Journal of Archaeological Science: Reports. - 2016. - Vol. 8. - P. 121-134. DOI: $10.1016 /$ j.jasrep.2016.05.054

2. Using an Unmanned Aerial Vehicle (UAV) to capture micro-topography of Antarctic moss beds / Arko Lucieer, Darren Turner, Diana H. King, Sharon A. Robinson // International Journal of Applied Earth Observation and Geoinformation. - 2014. - Vol. 27. - P. 53-62. DOI: $10.1016 /$ j.jag.2013.05.011

3. Тайманова Г.К., Пак Р.Е. Беспилотные летательные аппараты для мониторинга нефтепроводов // International Scientific and Practical Conference World science. - 2018. Vol. 1, № 1 (29). - P. 42-43.

4. Чуенкова А.А., Логачева А.В. Беспилотные летательные аппараты в геоинформационной сфере // Конструкторское бюро. - 2018. № 3. - С. 34-42.

5. Ямщиков В.А. Беспилотные летательные аппараты // Интернаука. - 2019. - № 45-1 (127). C. 75-77.

6. Смирнова М.С. Особенности разработки и обеспечения качества программных комплексов управления группировками беспилотных летательных аппаратов // Наука и бизнес: пути развития. - 2019. - № 7 (97). C. $119-123$.

7. Расчет маршрутов для группы беспилотных аппаратов / К.С. Подшивалова, С.Ф. Подшивалов, Н.В. Комолова, Ю.А. Павлова, С.В. Дунаев // Дневник науки. - 2019. - № 10 (34). C. 13-15.

8. Gabrlik P. The Use of Direct Georeferencing in Aerial Photogrammetry with Micro UAV // IFAC-PapersOnLine. - 2015. - Vol. 48, issue 4. P. 380-385. DOI: 10.1016/j.ifacol.2015.07.064

9. Satoshi Ishiguro, Hiroya Yamano, Hiroyuki Oguma Evaluation of DSMs generated from multi-temporal aerial photographs using emerging structure from motionmulti- view stereo technology // Geomorphology. - 2016. - Vol. 268. - P. 64-71. DOI: $10.1016 /$ j.geomorph.2016.05.029

10. Aber J.S., Marzolff I., Ries J.B. Chapter 1: Introduction to Small-Format 
Aerial Photography // Small-Format Aerial Photography. - 2010. - P. 1-13. DOI: 10.1016/B978-0-12-812942-5.00001-X

11. The Lusi drone: A multidisciplinary tool to access extreme environments / G. Di Stefano, G. Romeo, A. Mazzini, A. Iarocci, S. Pelphrey // Marine and Petroleum Geology. - 2018. - Vol. 90. - P. 26-37. DOI: $10.1016 /$ j.marpetgeo.2017.07.006

12. Colomina I., Molina P. Unmanned aerial systems for photogrammetry and remote sensing: A review // ISPRS Journal of Photogrammetry and Remote Sensing. - 2014. - Vol. 92. P. 79-97. DOI: 10.1016/j.isprsjprs.2014.02.013

13. Siebert S., Teizer J. Mobile 3D mapping for surveying earthwork projects using an Unmanned Aerial Vehicle (UAV) system // Automation in Construction. - 2014. - Vol. 41. - P. 1-14. DOI: $10.1016 /$ j.autcon.2014.01.004

14. Margaret Arblaster 11: New entrants into airspace - unmanned aircraft (drones) and increased space transportation // Air traffic management. - 2018. - P. 235-255. DOI: 10.1016/B978-0-12-811118-5.00011-4

15. СТО «ЛУКОЙ» 1.8.-2008. Карты и планы цифровые топографические, Требования к составу, структуре, содержанию, форматам представления, правилам обновления в ОАО «Лукойл» и организациях группы «Лукойл». - Пермь, 2008. - 45 с.

16. Руководство пользователя Agisoft PhotoScan Professional Edition, версия 1.2. 2004. - M., 2004. - 90 c.

17. Краснопевцев Б.В. Фотограмметрия. М.: УПП «Репрография» МИИГАиК, 2008. $160 \mathrm{c}$.

18. Токтошов Г.Ы. О создании геоинформационных система на основе гиперсетей для организации инженерной инфраструктуры современных городов // Известия Томского политехнического университета. Инжиниринг георесурсов. 2016. - Т. 327, № 1. - С. 48-55.

19. Ковязин В.Ф., Романчиков А.Ю. Метод кадастровой оценки лесных земель с представлением результатов в виде геоинформации // Известия Томского политехнического университета. Инжиниринг георесурсов. - 2017. - $\quad$ Т. 328, № $2 . \quad-$ C. 104-112.

20. Об экологических характеристиках огнетушащих веществ, используемых при тушении нефти и нефтепродуктов / И.Ф. Дадашов, В.М. Лобойченко, В.М. Стрелец, М.А. Гурбанова, Ф.М. Гаджизаде, А.И. Морозов // SOCAR Proceedings. - 2020. - № 2. C. 79-84. DOI: 10.5510/OGP20200100425

21. Алигулиев Р.М., Фаталиев Т.Х., Мехтиев Ш.А. Промышленный интернет вещей: эволюция автоматизации в нефтегазовом комплексе // SOCAR Proceedings. - 2019. № 2. - C. 66-71. DOI: 10.5510/OGP20190200391

22. Оптимизация энергетической стратегии нефтегазового предприятия / А.М. Шаммазов, И.А. Шаммазов, О.В. Смородова, С.В. Китаев, И.Р. Байков // SOCAR Proceedings. - 2018. № 4. - C. 65-69. DOI: 10.5510/OGP20180400373

23. Кремчеев Э.А., Данилов А.С., Смирнов Ю.Д. Состояние метрологического обеспечения систем мониторинга на базе беспилотных воздушных судов // Записки горного института. - 2019. - Т. 235. - С. 96-105. DOI: 10.31897/PMI.2019.1.96

24. Catur Aries Rokhmana The Potential of UAV-based Remote Sensing for Supporting Precision Agriculture in Indonesia // Procedia Environmental Sciences. - 2015. - Vol. 24. P. 245-253. DOI: 10.1016/j.proenv.2015.03.032

25. Construction and Accuracy Test of 3D Model of Non-Metric Camera Images Using Agisoft PhotoScan / Xiu quan Li, Zhu and Chen, Li ting Zhang, Dan Jia // Procedia Environmental Sciences. - 2016. - Vol. 36. P. 184-190. DOI: 10.1016/j.proenv.2016.09.031

26. Pajares G., Overview and Current Status of Remote Sensing Applications Based on Unmanned Aerial Vehicles (UAVs) // Photogrammetric Engineering \& Remote Sensing. - 2015. - Vol. 81, issue 4. - P. 281-329. DOI: $10.14358 /$ PERS.81.4.281

27. UAVs as remote sensing platform in glaciology: Present applications and prospects / Anshuman Bhardwaj, Lydia Sam, F. Akanksha, Javier Martín-Torres, Rajesh Kumar // Remote Sensing of Environment. 2016. - Vol. 175. - P. 196-204. DOI: $10.1016 /$ j.rse.2015.12.029 
28. Пространственные модели, разрабатываемые с применением лазерного сканирования на газоконденсатных месторождениях Северной строительно-климатической зоны С.Н. Меньшиков, А.А. Джалябов, Г.Г. Васильев, И.А. Леонович, О.М. Ермилов // Записки горного института. - 2019. - Т. 238. C. 430-437. DOI: 10.31897/pmi.2019.4.430

29. Визуализация программного обеспечения на базе средств виртуальной реальности геопростраственных данных. Обзор и перспективы разработки / В.Л. Авербух, Н.В. Авербух, П.А. Васев, И.Л. Гвоздарев, Г.И. Левчук, Л.О. Мелкозеров // Известия Томского политехнического университета. Инжиниринг георесурсов. - 2020. - Т. 331, № 1. C. 195-210. DOI: 10.18799/24131830/2020/1/2461

30. Зоев И.В., Марков Н.Г., Рыжова С.Е. Интеллектуальная система компьютерного зрения беспилотных летательных аппаратов для мониторинга технологических объектов предприятий нефтегазовой отрасли // Известия Томского политехнического университета. Инжиниринг георесурсов. - 2019. - Т. 330, № 11. C. 34 49. DOI: $10.18799 / 24131830 / 2019 / 11 / 2346$

31. Латыпов А.И., Яббарова Е.Н. Об интерпретации данных статического зондирования грунтов // Известия Томского политехнического университета. Инжиниринг георесурсов. - 2019. - Т. 330, № 10. - С. 82-90. DOI: $10.18799 / 24131830 / 2019 / 10 / 2300$

32. Организация системы геоинформационного мониторинга состояния земельных ресурсов прибрежной зоны Новосибирского водохранилища / А.П. Карпик, Е.И. Аврунев, Н.И. Добротворская, А.В. Дубровский, О.И. Малыгина, В.К. Попов // Известия Томского политехнического университета. Инжиниринг георесурсов. - 2019. - Т. 330, № 8. C. $133-145$. DOI: 10.18799/24131830/2019/8/2219

33. Епифанова Е.А., Строкова Л.А. Анализ деформаций прожекторной мачты при помощи наземного лазерного сканирования и метода конечных элементов // Известия Томского политехнического университета. Инжиниринг георесурсов. - 2019. - Т. 330, № 5. - С. 7-17. DOI: $10.18799 / 24131830 / 2019 / 5 / 267$

34. Bharat Rao, Ashwin Goutham Gopi, Romana Maione The societal impact of commercial drones // Technology in society. - 2016. - Vol. 45. - P. 83-90. DOI: 10.1016/j.techsoc.2016.02.009

35. Duarte Use of unmanned aerial vehicles for efficient beach litter monitoring / Cecilia Martin, Stephen Parkes, Qiannan Zhang, Xiangliang Zhang, M. Carlos // Marine pollution bulletin. - 2018. - Vol. 131. - P. 662-673. DOI: 10.1016/j.marpolbul.2018.04.045

36. Konar B., Iken K. The use of unmanned aerial vehicle imagery in intertidal monitoring // Deep-sea research part II: topical studies in oceanography. - 2018. - Vol. 147. - P.79-86. DOI: $10.1016 /$ j.dsr2.2017.04.010

37. Safety and security management with unmanned aerial vehicle (UAV) in oil and gas industry / Jaeyoung Cho, Gino Lim, Taofeek Biobaku, Seonjin Kim, Hamid Parsaei // Procedia manufacturing. - 2015. - Vol. 3. - P. 1342-1349. DOI: $10.1016 /$ j.promfg.2015.07.290

38. Волкова И.И., Белов Н.С., Шапльгина Т.В. Геопространственный анализ природноантропогенной трансформации эоловых прибрежно-морских природных комплексов с использованием наземного лазерного сканирования // Маркшейдерский вестник. 2020. - № 1 (134). - С. 41-45.

39. Прокоп А.Д. Обоснование точности определяемых величин при производстве маркшейдерских съемок с применением программно-аппаратных комплексов // Маркшейдерский вестник. - 2020. - № 1 (134). C. 46-49.

40. Павлов В.И. Аэрофотосъемка водного пространства // Маркшейдерский вестник. 2019. - № 6 (133). - С. 40-44.

41. Волков В.И., Волков Н.В., Волков О.В. Новый подход к применению маркшейдерскогеодезических наблюдений для контроля техногенных последствий разработки нефтегазовых месторождений // Маркшейдерский вестник. - 2018. - № 3 (124). C. $45-50$.

42. Чан Т.Ш., Кузин А.А. Анализ влияния кривизны Земли на результаты спутниковых и традиционных измерений в топоцентрической системе координат // Маркшейдерский вестник. - 2018. - № 6 (127). C. $38-43$. 
43. Вердиев С.Б. Анализ погрешности геодезических средств измерения дистанций, вызванных атмосферными осадками // Маркшейдерский вестник. - 2018. - № 6 (127). C. 44-48.

44. Клочков В.В., Никитова А.К. Метод прогнозирования спроса на беспилотные летательные аппараты и работы по воздушному патрулированию // Проблемы прогнозирования. - 2007. - № 6 (105). C. $144-152$.

45. Никишев В.К., Сергеев Е.С. Беспилотные летательные аппараты - моделирование динамики и перспективы развития // Теоретические и прикладные аспекты современной науки. - 2014. - № 6-3. - С. 85-87.

Please cite this article in English as:

Anikaeva A.D., Martyushev D.A. Assessment of the Unmanned Aerial Vehicle Potential Application in the Oil and Gas Industry. Perm Journal of Petroleum and Mining Engineering, 2020, vol.20, no.4, pp.344-355. DOI: $10.15593 / 2712-8008 / 2020.4 .4$

Просьба ссылаться на эту статью в русскоязычных источниках следующим образом: Аникаева А.Д., Мартюшев Д.А. Оценка потенциала применения беспилотных летательных аппаратов в нефтегазовой отрасли // Недропользование. - 2020. - T.20, №4. - C.344-355. DOI: 10.15593/2712-8008/2020.4.4 